\title{
The effect of lignocellulosic filler types and concentrations on the mechanical properties of wood plastic composites produced with polypropylene having various melt flowing index (MFI)
}

\author{
Farklı erime akış indeksine sahip polipropilenlerle üretilen odun plastik \\ kompozitlerin mekanik özellikleri üzerine lignoselülozik dolgu maddesi \\ türü ve kullanım oranının etkisi
}

\begin{abstract}
Received/Geliș Tarihi: 01.11.2016, Accepted/Kabul Tarihi: 01.03.2017
* Corresponding author/Yazıșılan Yazar

Abstract

In this study, the types and loading of lignocellulosic fillers on the properties of different melt flow index (MFI) polypropylene (PP) based wood plastic composites (WPCs) were determined. Olive pirinas and wood flour (Pinusbrutia Ten.) were used as lignocellulosic fillers at the loading rate of $20 \%$ and $40 \%$. Composites were produced by mixing wood flour or pirinas, wax, maleic anhydride grafted polypropylene (MAPP) and low or high MFI PP in a high intensity density mixer. The homogenous mixture was extruded using a single screw extruder with five heating zones. Extrudates were pelletized and composite specimens were injection molded. Control specimens were produced without adding any filler. The physical and mechanical and thermal properties were determined. It is stated that there is no effect of the melt flow index on the some properties of wood plastic composite, however; the mechanical properties compensates the values stated as in ASTM D 6662 standards even though it varies according to the types and rates of the fillers.
\end{abstract}

Vedat ÇAVUȘ ${ }^{*}$, Fatih MENGELOĞLU1

${ }^{1}$ Department of Forest Industry Engineering, Faculty of Forestry, Kahramanmaras Sutcuimam University, Kahramanmaras Turkey vedatcavus@hotmail.com,fmengelo@ksu.edu.tr

doi: $10.5505 /$ pajes.2017.80000 Special Issue Article/Özel Sayı Makalesi
Keywords: Wood plastic composite, Melt flow index, Pine wood Flour, Olive pirinas, Polypropylene, Mechanical properties

\section{Introduction}

Wood-plastic composites (WPCs) are materials that combine wood and polymer in a certain matrix. The WPCs consist of thewood flour, polymer and additives in different amounts. The manufacturing of these are quite similar with the manufacturing process and techniques thermoplastic polymers. The WPCs have been used highly in many areas, applications and industries since the 1990s [1]. As the population grows, the need of alternative raw materials is rising. The procedure of recycling waste lignocellulosic materials decreases the need of raw materials. Manufacturing the WPCs lignocellulosic materials are used as filler [2]. Wood flour and plastic matrix constitute the main ingredients in WPC formulations. The amounts of wood flour vary in the formulations and wood flour content of up to $70 \%$ is currently used in commercial WPC products. The amount of wood flour in WPCs significantly influences bothprocessing and end-use

\begin{abstract}
Öz
Bu çalışmada, lignoselülozik dolgu maddesi türü, kullanım oranı ve erime akıs indeksinin odun plastik kompozitlerin (OPK) özelliklerine etkisinin belirlenmesi hedeflenmiştir. Lignoselülozik dolgu maddesi olarak zeytin pirinası ve kızılçam odun unu $\% 20$ ve \%40 oranlarında kullanılmıştır. Kızılçam odun unu veya zeytin pirinası, vaks ve maleik anhidrit graftlanmıș polipropilen (MAPP)ve yüksek veya düșük erime akıs indeksine sahip polipropilen üretim reçetesine göre yüksek devirli mikser yardımıyla homojen bir șekilde karıștırılmıștır. Homojen karışım öncelikle tek vidalı eksturuder de karıștırılarak odun plastik kompozit karıșımları olușturulmuş ve bu karışımlar kırıcı yardımıyla pelletler haline dönüștürülmüstür. Üretilen pelletler kullanılarak enjeksiyon kalıplama makinesinde deney numuneleri üretilmiştir. Kontrol numuneleri dolgu maddesi katılmadan üretimler gerçekleştirilmiştir. Üretilen deney numunelerinin fiziksel ve mekanik özellikleri belirlenmiştir. Erime akış indeksinin OPK'lerin özelliklerine önemli bir etkisinin olmadığı buna karșın dolgu maddesi türü ve oranına göre değișkenlik göstermesine rağmen mekanik özelliklerin ASTM D 6662 standardında belirlenen değerleri karșıladiğı tespit edilmiştir.
\end{abstract}

Anahtar kelimeler: Odun plastik kompozit, Erime akış indeksi, Kızılçam odunu unu, Zeytin pirinası, Polipropilen, Mekanik özellikler

properties. The type of wood species constitutes another important factor to consider in WPCs [3].

The Turkish red pine (Pinus brutia Ten.) is naturally grown in Turkey, especially in the sea side regions of the Mediterneaen, the Aegean and the Marmara region [4]. Turkish red pine (Pinusbrutia Ten.), wood has been used in the paper and cellulosic industries, construction material, packing case, agricultural tools, wooden wire poles, mine poles, fence, tools and cases and also in the construction of marine vehicles [5], [6]. As the amount of the residue of Turkish red pine wood varies according to being cut saw machine or a gang saw, a log is $60 \%$ efficient [7]. In other words $40 \%$ of a logs are residue.

Olive trees are spread between lattitudes of 30 and 45 degrees of northern and southern hemisphere, especially having Mediterranean climate conditions, over the five continents of the world[8]. Turkey, situated in Mediterranean Basin is one of the most important olive and olive oil producers in the 
world[9]. Pirina which will be produced out of the olives and while of amount pirina and oil which is produced out of olives change according to the production technique, the type of the olives and the oil processing, 35-45 kg of pirina and 15-22 kg of olive oil is produced out of approximately $100 \mathrm{~kg}$ of olives [10].

The amount of residue pirina in the oil industry of Turkey is approximately 200.000 tons. Pirina, which is not well evaluated commercially is used as fuel, it is also purchased by distributes or is dumped to the wasteland. This is also causes environmental pollution [11].

The purpose of this work is to study the effect of concentration and type of lignocellulosic fillers on the mechanical properties of polypropylene based WPCs. Turkish red pine flour (RPF) and olive pirinas (OF) was used as lignocellulosic materials and high and low melt flow index polypropylene was utilized as polymeric matrices. Some mechanical properties such as tensile strength, flexural strength, impact strength and linear burning rate of WPCs were evaluated.

\section{Materials and method}

\section{$2.1 \quad$ Materials}

In this study; lignocellulosic fillers Turkish red pine flour (RPF)and olive pirinas(OP) were used. Turkish red pine particles were supplied by wood working atelier and olive pirinas supplied from olive oil mill in Kahramanmaraş city. High and low melt flow index Polypropylenes (MH 418 and EH 241) used in the experiments was obtained from Petkim Petrochemical Co. in Turkey. Some mechanical, physical and thermal properties of Polypropylene were shown in Table1.

Table 1: Some properties(Physical, mechanical and thermal) of the various MFI Polypropylene [12].

\begin{tabular}{cccc}
\hline \multirow{2}{*}{ Properties } & \multicolumn{2}{c}{ Polypropylene } & \multirow{2}{*}{ Unit } \\
& MH 418 & EH 241 & \\
\hline Melt Flow Rate & 4.5 & 24 & $\mathrm{~g} / 10 \mathrm{~min}$. \\
Density $\left(23^{\circ} \mathrm{C}\right)$ & 0.905 & 0.905 & $\mathrm{~g} / \mathrm{cm}^{3}$ \\
Tensile StrenghtatYield & 34 & 39 & $\mathrm{Mpa}$ \\
Tensile Strenght at Break & 42 & 32 & $\mathrm{Mpa}$ \\
Color b Value (10D65) & 1.8 & 1.5 & - \\
Melting Point (DSC) & 163 & 163 & ${ }^{\circ} \mathrm{C}$ \\
DeflectionTemperature & 113 & 114 & ${ }^{\circ} \mathrm{C}$ \\
Izod Impact Strenght & 21.6 & 14.7 & $\mathrm{~J} / \mathrm{m}$ \\
Rockwell Hardness & 94 & 96 & $\mathrm{Rscale}$ \\
Flexural Modulus $\left(23^{\circ} \mathrm{C}\right)$ & 1450 & 1470 & $\mathrm{Mpa}$ \\
\hline
\end{tabular}

For coupling agents; maleic anhydrite grafted polypropylene (MAPP) (Licomont AR 504 supplied from Clariant) and for lubricant paraffin wax (K.130.1000)were added of weight of $3 \%$ to improve the performances of WPCs. Some properties of coupling agent and wax were given in Table 2 .

Table 2: Some properties of maleic anhydrite grafted polypropylene and wax.

\begin{tabular}{ccc}
\hline Properties & $\begin{array}{c}\text { LicomontAR 504 } \\
\text { (MAPP) }\end{array}$ & Paraffin wax \\
\hline Viscosity $\left(140^{\circ} \mathrm{C}\right)$ & $800 \mathrm{mPa} . \mathrm{S}$ & - \\
Density at $23^{\circ} \mathrm{C}$ & $0.91 \mathrm{~g} / \mathrm{cm}^{3}$ & $0.93 \mathrm{~g} / \mathrm{cm}^{3}$ \\
Acid value & $41 \mathrm{mg} \mathrm{KOH} / \mathrm{g}$ & - \\
Softening point & $156^{\circ} \mathrm{C}$ & $56-58^{\circ} \mathrm{C}$ \\
Appearance & Yellowish fine grain & White dust \\
\hline
\end{tabular}

\subsection{Composite manufacturing}

The lignocellulosic fillers RPF and OP were turned into flour form with using a Wiley mill. These flours were classifiedin 2040-60-80-100 to 200 mesh-sizes. Classified particles (Figure 1) which passed by a 40 mesh and which were remain on 60 mesh ( 0.25 mmor 250 micron) were used. The 60 mesh Turkish red pine flour (RPF) and olive pirinas flour (OP) were dessicated in oven for 24 hours at $103{ }^{\circ} \mathrm{C}( \pm 2)$. The moisture content of dried filler materials was below $1 \%$.

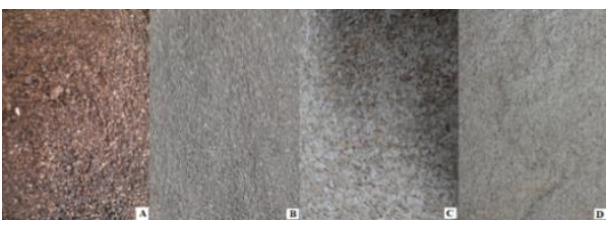

Figure 1: Used lignocellulosic fillers (a): olive pirinas, (b): 60 mesh olive pirinas flour form, (c): Turkish red pine, (d): 60 mesh Turkish red pine flour form.

Using the formulation; lignocellulosic fillers, polypropylene (PP) with high and low melt flow index, lubricant and maleic anhydrite grafted polypropylene were mixed in a mixer (900-1000 rpm in $2 \mathrm{sec}$.) to produce for homogeneous blend. The manufacturing schedule of the study was given Table 3. Stabilizing the rates of MAPP and wax in this mixture, pirinas and wood flour were added with the rates of $20 \%$ and $40 \%$. Wax and MAPP were added only into control test specimens without any filler materials.

Table 3: Manufacturing schedule of WPCs.

\begin{tabular}{cccc}
\hline Factors & \multicolumn{3}{c}{ Levels } \\
\hline Factor 1: MFI of PP & H-MFI & L-MFI & OP \\
Factor 2: Filler Type & RPF & 20 & 40 \\
Factor 3: Filler Rate (\%) & 0 & 20 \\
\hline
\end{tabular}

H-MFI: High melt flow index, L-MFI: Low melt flowindex, RPF: Turkish red pine flour, OP: olive pirinas flour.

By using a single-screw extruder at $40 \mathrm{rpm}$ screw speed in the temperatures (from barrel to die) of $170-180-185-190-200^{\circ} \mathrm{C}$ respectively these blends were compounded. Extruded specimens were cooled in water pool $\left(23^{\circ} \mathrm{C} \pm 2\right)$ and then pelletized into pellets form with grinding machine. The pellets were dessicated in oven at $103{ }^{\circ} \mathrm{C}( \pm 2)$ for 24 hours. The moisture content of dried wood plastic pellets was below $1 \%$ before the injection molding.The injection molding machine (HAIDA HDX-88) was used for manufacture test specimens. The temperatures of injection molding machine were 180$190-200^{\circ} \mathrm{C}$ (from feed zone to die zone). The injection pressure, speed and cooling speed were 5-6 MPa, $80 \mathrm{~mm} / \mathrm{Sec}$. and 30sec. respectively.

\subsection{Composites testing}

All test specimens were tested in a climate-controlled testing laboratory. Depending on the ASTM D 792 standard, the densities of WPCs were evaluted by a water displacement technique.According to ASTM D 790, ASTM D 638 and ASTM D 256 flexural, tensile, and impact strenght properties of all specimens were determined respectively. Five specimens were tested for each group. Universal Testing machine (Zwick Roell Z010) was used for flexural and tensile strenght tests. The notched specimens were tested for impact strenght on HIT5.5P machine by Zwick ${ }^{\mathrm{TM}}$. Before the test using a Polytest notching cutter machine by RayRan ${ }^{\mathrm{TM}}$ notches were added. 
Depending on the ASTM D 635 standart, horizontal burning test (Figure 2) was performed. The dimensions of specimens were $4 \mathrm{X} 13 \mathrm{X} 125 \mathrm{~mm}$. The average burning rate was determined as to the mark in $\mathrm{mm} / \mathrm{min}$. Ten specimens were burned for each group. Atlas HVUL2 horizontal vertical flame chamber test machine was used in this study.

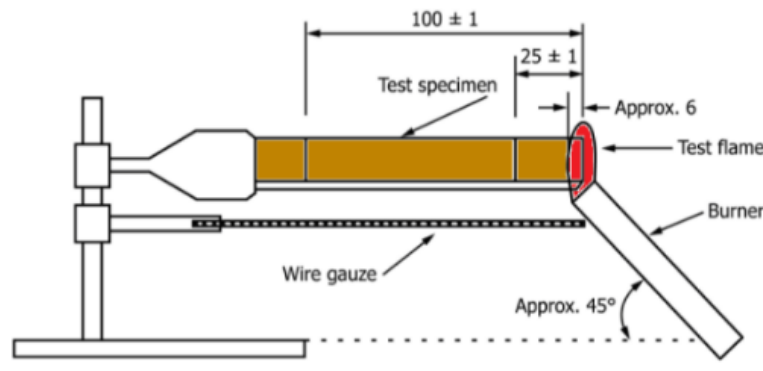

Front view

Figure 2: Horizontal burning test procedure (adapted from ASTM D 635).

For the statistical analysis; Design-Expert ${ }^{\circledR}$ statistical software (Version 7.0.3) program was used. The composite design accomplished with the central composite program(CCD).

\section{Results and discussion}

In this study, the effect of melt flow index (MFI) of PP, filler type and filler rate on the some properties of WPCs were studied. Density, flexural (flexural strength, flexural modulus), tensile (tensile strength, tensile modulus, elongation at break), impact, hardness and burning rate properties were determined.

All manufactured WPCs were in the density range of 0.89 and $1.04 \mathrm{~g} / \mathrm{cm}^{3}$. The interaction charts of the density were presented in Figure 3. Composites manufactured with H-MFI and L-MFI was presented in Figure 3A and 3B, respectively. Statistical analysis showed that MFI of PP was not significantly important for density. Both H-MFI and L-MFI composites provided similar densities $(\mathrm{P}=0.1736)$. Both Filler type and filler rate, had a significant effect on density $(\mathrm{P}=0.0033$ and $\mathrm{P}<0.0001)$. Both filler increased density. This increase was due to the higher cell wall density of lignocellulosic Materials [13],[14]. Between RPF and OP fillers, RPF provided higher density values than OP filler.

Flexural strength values ranged from 29.38 and 46.16MPa. The interaction charts of the flexural properties were presented in Figure 4. Statistical analysis demonstrated that MFI of PP significantly impacted the flexural strength $(\mathrm{P}<0.0001)$. H-MFI provided highest flexural strength for RPF filled composites while L-MFI gave highest values for OP filled ones.

In the flexural modulus properties of PP based composites, values ranged from 1108 to $2519 \mathrm{MPa}$. Similar to the flexural strength, MFI of PP was also effective on flexural modulus $(\mathrm{P}<0.0001)$. Regardless of filler type, H-MFI composites provided higher flexural modulus values. Results also showed that flexural modulus properties were affected by filler types and filler rates $(\mathrm{P}<0.0001)$. Both filler improved the modulus properties. It should be noted that RPF filled ones had much higher modulus values than OP filled ones. Lowest modulus values were gathered for unfilled samples. This can be explained that lignocellulosic fillers and polymers have different modulus of elasticity from each other. Lignocellulosic fillers have higher modulus of elasticity than polymer [15],[16].
This resulted in improved flexural modulus values compared to unfilled ones. Therefore, flexural modulus increased with the rise of lignocellulosic filler loading [2].
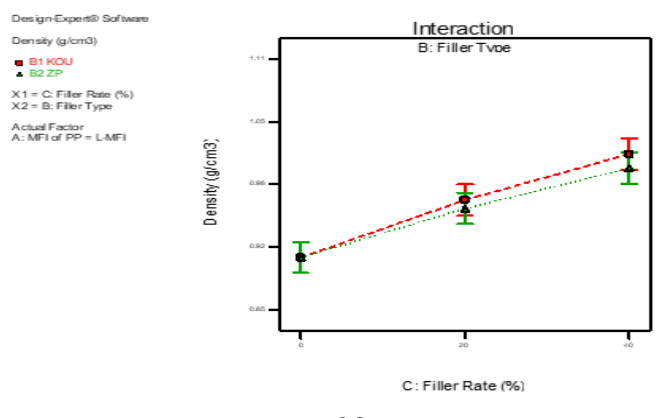

(a)
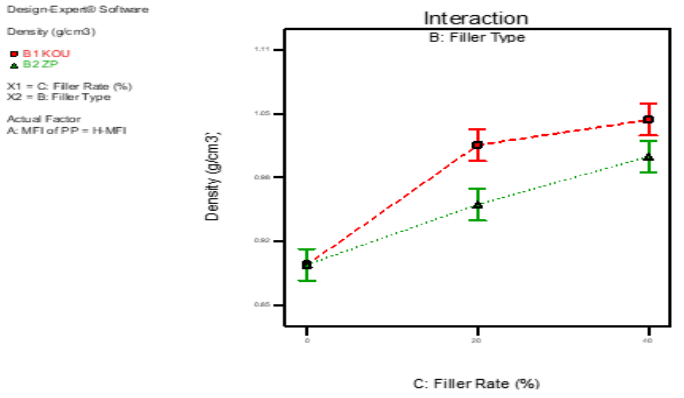

Figure 3: Interaction charts of density of the composites,

(a): H-MFI, (b): L-MFI.

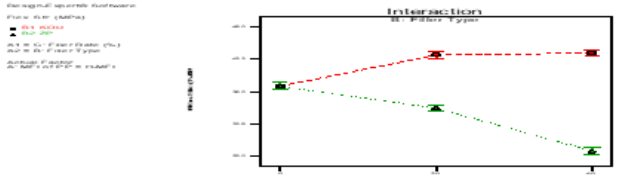

(a)

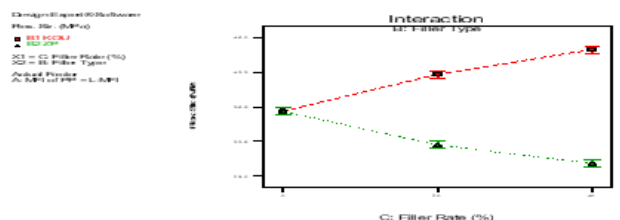

(b)

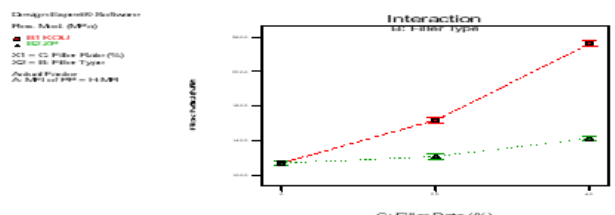

(a)

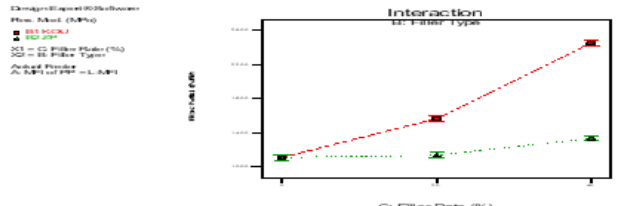

(b)

Figure 4: Interaction charts of flexural properties of the composites: a - Flexural strength; b - Flexural modulus,

(a): HMFI, (b):LMFI. 

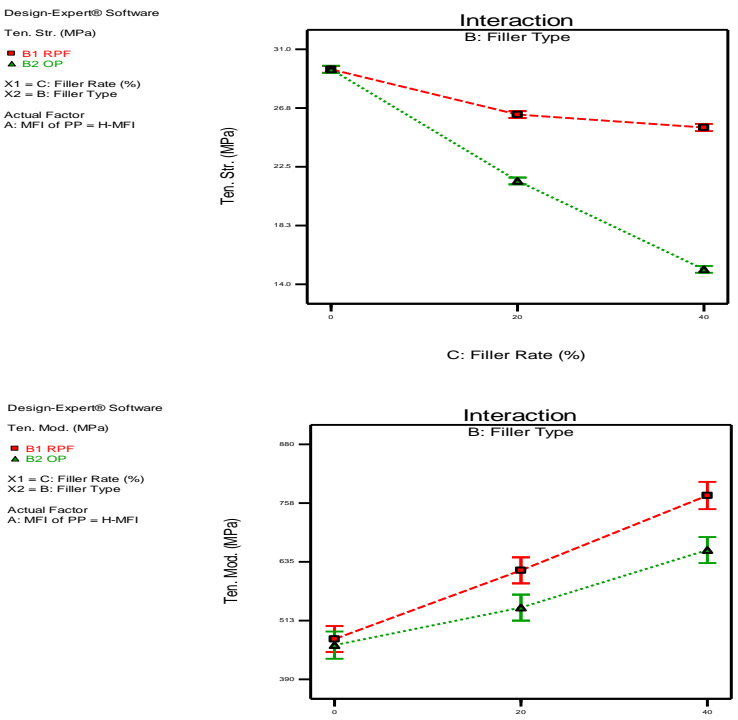

C: Filler Rate (\%)
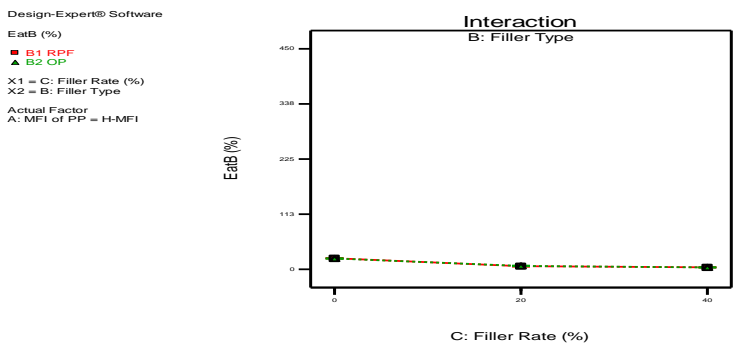

(a)

(a)

(a)
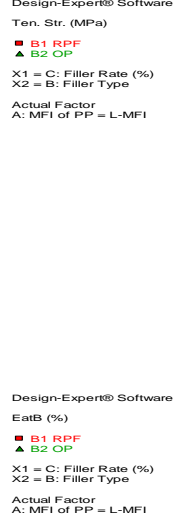

Actual Factor A: MFI of PP - L-MFI

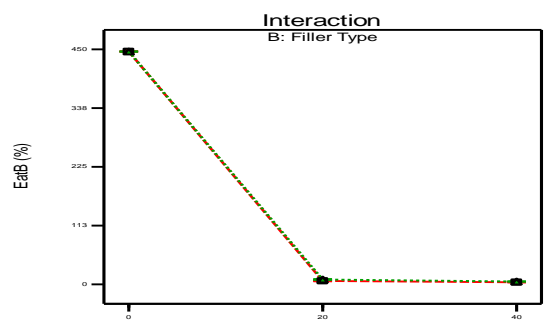

C: Filler Rate (\%)

(b)

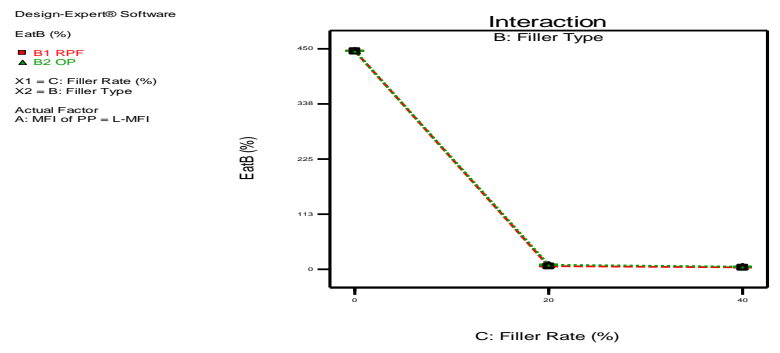

(b)

Figure 5: Interaction graphs of tensile properties of the composites: (a): Tensile strength; (b): Tensile modulus; (c): Elongation at break; (a): H-MFI, (b): L-MFI.

The average tensile strength values of the specimens were in the range of 15.12 and $30.03 \mathrm{MPa}$. Statistical analysis showed that MFI of PP was not significantly important for flexural strength.Both H-MFI and L-MFI composites provided similar tensile strength values $(\mathrm{P}=0.0852)$. Regardless of $\mathrm{MFI}$, both filler type and filler rate significantly reduced the tensile strengths $(\mathrm{P}<0.0001)$. RPF filled PP composites provided higher tensile strength values compared to OP filled ones.

Tensile modulus values were in the range of 469.80 and 834.41 MPa.MFI of PP did not have significant effect on tensile modulus $(\mathrm{P}=0.9850)$. Both $\mathrm{H}-\mathrm{MFI}$ and $\mathrm{L}-\mathrm{MFI}$ composites provided similar results. Regardless of MFI type, both filler type and filler rate significantly increased the tensile strength values $(\mathrm{P}<0.0001)$. RPF filled PP composites provided higher tensile modulus valuescompared to OP filled ones. Lignocellulosic filler usually improves tensile modulus of the thermoplastic composites. It can be explained by the rule of mixtures [17].

At the point of elongation at break valueswere in the range of $3.90 \%$ and $455.23 \%$ and MFI type had significant effecton them $(\mathrm{P}<0.0001)$. L-MFI has higher elongation at break values compared to H-MFI. It should be noted that when the lignocellulosic filler was added into polymer matrix elongation at break levels were significantly scaled down. Even $20 \%$ filler addition had reduced pure L-MFI specimens' elongation at break values from $450 \%$ to $7 \%$. Polymercomposites became stiffer when the amount of filler in the matrix was increased. So, the elongation at break values was decreased.

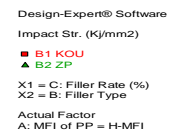

$\times 1-C:$ Filer Rate $(\%)$
$\times 2=-$ : Filer Type
Actual Factor

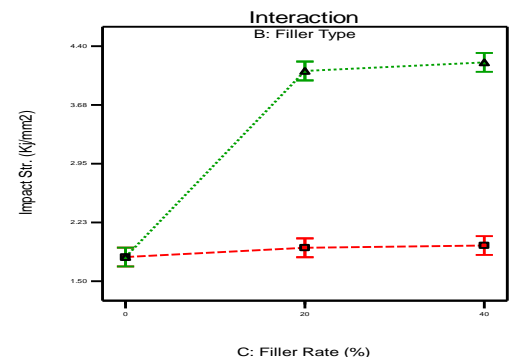

(a)

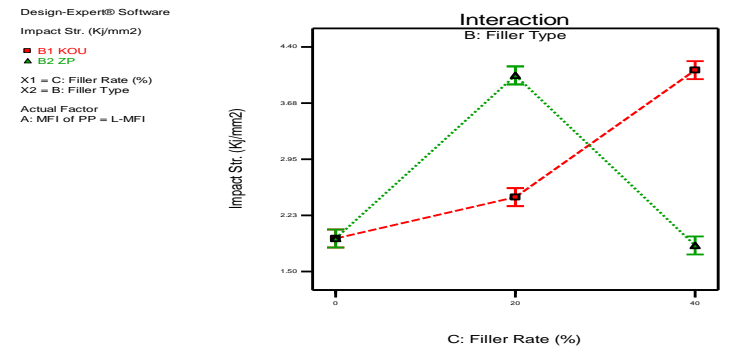

(b)

Figure 6: Interaction charts of impact strength of the composites (a): H-MFI, (b):L-MFI. (b)

) 
Interaction charts of notched impact strength are shown in Figure 6. Notched impact strength levels were significantly effected with the MFI of $\mathrm{PP}(\mathrm{P}=0.0246)$, filler types $(\mathrm{P}<0.0001)$ and filler rates $(\mathrm{P}<0.0001)$. The range of the notched impact strength values were 1.80 to $4.20\left(\mathrm{~kJ} / \mathrm{m}^{2}\right)(\mathrm{P}<0.0001)$. Filler is significantly effective on impact strength. This usually arises from increasing of brittleness of the composite material [18].
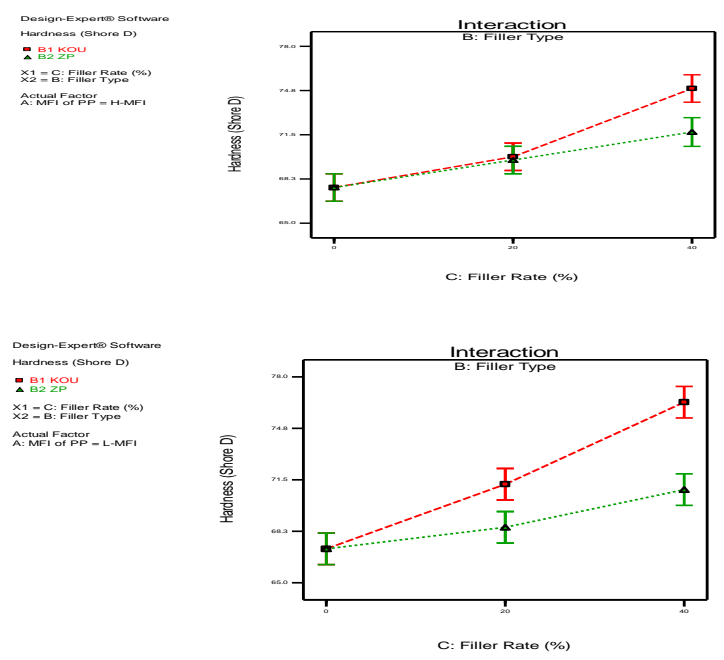

Figure 7: Interaction charts of hardness of the composites(Shore-D).

The mean hardness values ranged from 67.14 to 74.90 (ShoreD). Interaction charts of hardness values were shown in Figure7. The hardness values were significantly affected by MFI of PP, filler types $(\mathrm{P}<0.0001)$ and filler rates $(\mathrm{P}<0.0001)$. L-MFI index provided slightly higher results than H-MFI ones. In addition RPF filled composites provided increased hardness values than OP filled ones. The hardness of the test specimens were increased depend on filler types and filler rate [19].

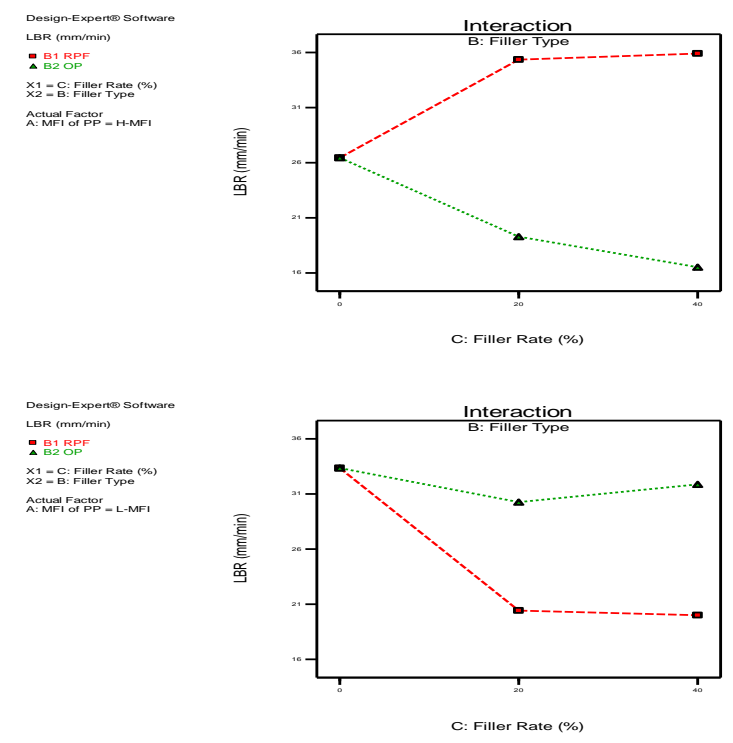

(a)

Figure 8: Interaction charts of burning rate of the composites(mm\min)
The charts of burning rate values was given in Figure 8 . The mean values were ranged for the burning rate from 16.52 to $35.90 \mathrm{~mm} \backslash \mathrm{min}$. These values were calculated by measuring the burned distance per minute. The highest burning rate means it burns faster. It was interesting to see that composites utilizing H-MFI matrix had the lowest burning rate when it was filled with OP. Oppositely, RPF filled composites provided lowest burning rate when L-MFI polymeric matrix was used. This can be related with heat capacity of the polymer, wood flour [20] and olive pirinas flour. There is a need for follow up studies to understand this behaviour.

\section{Conclusions}

Wood plastic composites with different melt flow index were measured and effect of filler type and filler rate on selected properties were evaluated. For the tensile strength and tensile modulus, melt flow index of the polymer did not have significant effect. If lignocellulosic filler present in the formulation, melt flow index also was not important. Regardless of MFI, filler rate and type had a significant effect on studied properties. RPF filled composites outperformed the OP filled ones. However, both fillers met the sufficient mechanical properties of ASTM D 6662. RPF and OP flour fillers from waste materials can be utilized in composite manufacturing.

\section{Acknowledgements}

This research was supported by KSU Scientific Research Fund (BAP) (Project number: 2015/3-63D).

\section{References}

[1] Hietala M. Extrusion Processing of Wood-Based Biocomposites. PhD Thesis, Luleå University of Technology, Luleå, Sweden, 2013.

[2] Mengeloğlu F, Başboğa H, Aslan T. "Selected propeties of furniture plant waste filled thermoplastic composites". Pro Ligno, 11(4), 199-206, 2015.

[3] Matuna M, Stark M. "The use of wood fibers as reinforcements in composites". Biofiber Reinforcement in Composite Materials Waltham, 6(1), 648-688, 2015.

[4] Sarıbaş M, Ekici B. "Kızılçamın (Pinusbrutia Ten.) Batı Karadeniz Bölgesindeki doğal yayilişi”. ZKÜ Bartın Orman Fakültesi Dergisi, 6(6), 127, 2004.

[5] Bozkurt Y. Önemli Bazı Ağaç Türleri Odunlarının Tanımı Teknolojik Özellikleri ve Kullanıș Yerleri. 2. baskı. İstanbul, Türkiye, Orman Fakültesi Yayınları, 1971.

[6] Yaltırık F, Efe A. Dendroloji Ders Kitabı GymnospermaeAngiospermae. 2. baskı. İstanbul, Türkiye, Orman Fakültesi Yayınları, 2000.

[7] Gürsu İ, Öktem E. "Asli ağaç türlerinin bıçkı sanayinde (şerit ve katrak testerelerde) çap kademelerine göre randımanlarının ve artıklarının saptanmasına ilişkin araştırmalar". Ormancılık Araștırma Enstitüsü Dergisi Teknik Bülten Serisi, Ankara, Türkiye, 70(2), 1975.

[8] Öztürk F, Yalçın M, Dıraman H. "Türkiye zeytinyağ ekonomisine genel bir bakıș". Gıda Teknolojileri Dergisi, 4(2), 35-51, 2009.

[9] Efe R, Soykan A, Cürebal İ, Sönmez S. Dünya'da, Türkiye'de, Edremit Körfezi Cevresinde Zeytin ve Zeytinyağı. Edremit, Türkiye, Edremit Belediyesi Kültür Yayınları, 2013. 
[10] Öcal A. Zeytinyağ Atık suyu ve Pirinanın Bitki Yetiştirilmesinde Kullanım Olanaklarının Araştırılması Yüksek Lisans Tezi, Çukurova Üniversitesi, Adana, Türkiye, 2005.

[11] Demirtepe M. Balık Yemlerinde Pirina ve Pirina Yağı Kullanımı Üzerine Araştırmalar. Yüksek Lisans Tezi, Ege Üniversitesi, İzmir, Türkiye, 2008.

[12] Petrokimya Holding AȘ. "Ürün Bilgi Formları ve Ürün Şartnameleri".

https://app.petkim.com.tr/web/files/urunler/tr/UR.12BF-U1213_1.pdf (27.08.2016)

[13] Mengeloglu F, Karakuş K. "Mechanical properties of injection-molded foamed wheat straw filled HDPE biocomposites: The effects of filler loading and coupling agent contents". Bioresources, 7 (3), 3293-3305, 2012.

[14] Karakuş K. Mengeloğlu, F. "Polycaprolactone (PCL) Based Polymer Composites Filled Wheat Straw Flour". Kastamonu Universitesi Orman Fakültesi Dergisi, 16(1), 264-268, 2016.

[15] Bouafif H, Koubaa A, Perré P, Cloutier, A. "Effects of fiber characteristics on the physical and mechanical properties of wood plastic composites". Composites: Part A, 40(1), 1975-1981, 2009.
[16] Chaharmahali M, Mirbagheri J, Tajvidi M, Najafi K, Mirbagheri Y. "Mechanical and physical properties of wood-plastic composite panels". Journal of Reinforced Plastics and Composites, 29(3), 310-319, 2010.

[17] Matuana LM, Park CP, Balatinecz JJ. “Cell morphology and propert relationships of microcellular foamed PVC/Wood-fiber composites". Polymer Enginering Science, 38(1), 1862-1872, 1998.

[18] Mengeloglu F, Karakus K. "Thermal degradation, mechanical properties and morphology of wheat straw flour filled recycled thermoplastic". Sensors, 8(1), 497-516, 2008.

[19] Mengeloğlu F, Kurt R, Gardner DJ, Oneil S. "Mechanical properties of extruded high density polyethylene and polypropylene wood flour decking board". Iranian Polymer Journal, 16(7), 477-487, 2007.

[20] Dönmez Çavdar, A. Mengeloglu F, Karakus K. "Effect of boric acid and borax on mechanical, fire and thermal properties of wood flour filled high density polyethylene composites". Measurement, 60(1), 6-12, 2015. 